\title{
Genetic Factors in Nonsyndromic Orofacial Clefts
}

\author{
Mahamad Irfanulla Khan ${ }^{10}$ Prashanth C.S. ${ }^{2}$ Narasimha Murthy Srinath ${ }^{30}$
}

${ }^{1}$ Department of Orthodontics \& Dentofacial Orthopedics, The Oxford Dental College, Bangalore, Karnataka, India

2 Department of Orthodontics \& Dentofacial Orthopedics, DAPM R.V. Dental College, Bangalore, Karnataka, India

${ }^{3}$ Department of Oral \& Maxillofacial Surgery, Krishnadevaraya

College of Dental Sciences, Bangalore, Karnataka, India

Global Med Genet 2020;7:101-108.
Address for correspondence Mahamad Irfanulla Khan, BDS, MDS, Department of Orthodontics \& Dentofacial Orthopedics, The Oxford Dental College, Bangalore, Karnataka 560068, India

(e-mail: drirfankhanmds@gmail.com).

\begin{abstract}
Keywords

- orofacial clefts

- nonsyndromic

- genetics

- gene mutation

- genome-wide association study

- linkage analysis
\end{abstract}

\section{Introduction}

Orofacial clefts (OFC) are the most common congenital malformations in the orofacial region causing a significant personal and social encumbrance. ${ }^{1-3}$ The etiology remains complex involving multiple genetic and environmental factors along with gene-environment interactions. ${ }^{4-7}$ Children born with clefts may have difficulties in sucking, speech, hearing, and unaesthetic facial features due to the anatomical deformities. ${ }^{8,9}$ OFCs generally require surgical reconstruction of the lip and palate at different stages from birth to adulthood, ${ }^{10}$ and their rehabilitation involves a multidisciplinary approach such as, pediatric care, speech and hearing therapy, dental and orthodontic treatment, genetic counseling, and other mental health therapy. ${ }^{11,12}$

published online

February 12, 2021
DOI https://doi.org/

10.1055/s-0041-1722951.

ISSN 2699-9404.

\section{Epidemiology}

The prevalence of OFCs ranges from 1 in 700 to 1,000 newborns worldwide ${ }^{13}$ and include cleft lip only (CLO), cleft palate only (CPO), and cleft lip and palate (CLP). ${ }^{14}$ They may occur as unilateral or bilateral, complete, or incomplete, and may involve the lip only, the palate only, or both. ${ }^{15}$

The prevalence of OFC varies according to geographical location, ethnicity, race, gender and socioeconomic status, ${ }^{16-19}$ Asians have the highest prevalence rate (1:500), the intermediate prevalence in Europeans (1:1000), and lowest in Africans (1:2500). ${ }^{20-22}$ In India, the incidence of clefts is around 1:800 to $1: 1000$, and three infants are born with some type of cleft every hour. ${ }^{23}$ These differences appear to persist even after migration, suggesting that they are mediated by genetic, rather than environmental

(c) 2021. The Author(s).

This is an open access article published by Thieme under the terms of the Creative Commons Attribution License, permitting unrestricted use, distribution, and reproduction so long as the original work is properly cited. (https://creativecommons.org/licenses/by/4.0/)

Georg Thieme Verlag KG, Rüdigerstraße 14, 70469 Stuttgart, Germany 
factors. ${ }^{24}$ Overall, 70\% of the OFCs are nonsyndromic (NS) and occur as isolated cases without any additional physical or cognitive deficits. In contrast, $30 \%$ of clefts are syndromic and are associated with a few other developmental anomalies. ${ }^{25}$

The frequency of occurrence of OFC differs with regard to gender and side of clefting. Cleft lip is more common in males at a 2:1 male to female ratio, whereas a cleft palate is more common in females. ${ }^{26}$ Approximately $90 \%$ of OFCs are unilateral with primarily left-sided involvement. ${ }^{27}$

\section{Development of Cleft Lip and Palate}

The development of lip and palate begins during the fourth week of gestation where migrating neural crest cells combine with mesodermal cells to establish facial primordia which consist of five different processes (medial nasal, lateral nasal, frontonasal, maxillary, and mandibular processes) derived from the first pharyngeal arch. ${ }^{28}$ Once facial prominences are formed, the nasal placodes invaginate to form the medial nasal process (MNP) and lateral nasal process (LNP). The maxillary processes initially grow medially, pushing the LNP toward the upper side. During the sixth and seventh weeks of gestation fusion of maxillary processes with each other and also with lateral and MNPs takes place to form upper lip and primary palate. ${ }^{29}$ Defect in fusion or failure in the growth of these processes results in clefts involving the upper lip, alveolus, and/ or primary palate.

The secondary palate begins to develop in the seventh week of embryogenesis; the maxillary processes initially outgrow as palatal shelves which move toward each other vertically. After proper growth they settle at a horizontal position above the tongue which entails much extracellular remodeling. ${ }^{30,31}$ The palatal shelves then fuse in the midline both anteriorly and posteriorly like a zipper that forms a midline epithelial seam (MES). The disintegration of MES is required to maintain palatal confluency, which may involve apoptosis, epithelial-mesenchymal transition (EMT), and cell migration. ${ }^{32}$ Effective fusion of the secondary palate results in complete separation of the oral and nasal cavities. Cleft palate can result from failure at any of the steps, including palatal shelves elevation, cell migration, or fusion.

In summary, a variety of cellular mechanisms such as cell proliferation, cell migration, cell growth, cell fusion, apoptosis, EMT, and extracellular remodeling are involved in a coordinated manner during the development of lip and palate. Therefore, disruption in the gene/s involved in these processes during lip and palate development may lead to an OFC.

\section{Glimpse into the History of Genetic Etiology of Orofacial Clefts}

Although the familiarity of OFC has long been noted, FoghAndersen was the first to provide the evidence for genetic factors contributing to the etiology of CLP from family-based studies where it was observed that the siblings of CLP patients had an increased frequency of cleft lip with or without cleft palate. ${ }^{33}$ This observation was further confirmed by studies on the familial distribution of congenital clefts of the lip and palate, ${ }^{34}$ and Dr. Clark Fraser published a review paper highlighting the conclusions of a workshop on CLP sponsored by the National of Institutes of Health of the United States, and he mentioned the etiology is indeed multifactorial. ${ }^{35}$ Later, more evidence in favor of contribution of genetic factors to the etiology of CLP accrued from segregation analysis ${ }^{36}$ and twin studies $^{37,38}$ where the monozygotic twins showed high prevalence rate (40\%) than the dizygotic twins (4\%).

\section{Role of Genetic Factors in the Etiology of Orofacial Clefts}

The etiology of OFCs involves genetic factors, environmental influences, and gene-environment interactions, all contributing to its susceptibility. Scientific literature evidence suggests that environmental factors such as maternal tobacco smoking and alcohol consumption, antiepileptic medications, maternal folate deficiency, infections, consanguinity, and geographical location are risk factors for NS cleft lip and palate (NSCLP). ${ }^{39-42}$

Advances in genetics and molecular biology techniques have discovered multiple genes and loci associated with CLP. This article provides an overview of the genes implicated in the etiology of NSCLP. Identification of specific genetic variation contributing to NSCLP has led to an increase in our understanding of the molecular pathogenesis of OFC.

\section{Genes Involved in the Etiology of Nonsyndromic Orofacial Clefts}

\section{Special AT-Rich Sequence-Binding Protein}

Special AT-rich sequence-binding protein (SATB2) is a DNA binding protein which binds with nuclear matrix attachment regions. It is involved in transcription regulation and chromatin remodeling process. In an animal study, mouse SATB2 is strongly expressed in the developing cleft palate and is similar to the human SATB2 protein. ${ }^{43}$ The identification of SATB2 gene responsible for the craniofacial dysmorphologies associated with deletions and translocations at 2q32-q33, only one region of the genome has been significantly associated with the development of isolated cleft palate. ${ }^{44}$ Glass syndrome characterized by cleft palate, gum hyperplasia, slight micrognathia, generalized osteoporosis, and mental retardation reported from Thai patient, ${ }^{45}$ was caused by SATB2 gene mutation. Recently, using salivary miRNAs showed that the SATB2 genes are involved in the development of the cleft palate and lip development. ${ }^{46}$-Table 1 provides the list of genes involved in the etiology of NS OFC in humans.

\section{B-Cell Leukemia/Lymphoma 3}

B-cell leukemia/lymphoma 3 (BCL3) is a proto-oncogene, acts as a transcriptional co-activator through NF-kappa-B target genes and located on 19q13.2. BCL3 gene has also shown a strong association with NS orofacial clefts (NSOCs). ${ }^{47}$ A case-parent trio study showed BCL3 influence risk of $\mathrm{CL} / \mathrm{P}$ through a parent-of-origin effect with the excess maternal transmission. ${ }^{48}$ Several studies in different 
Table 1 Genes involved in the etiology of nonsyndromic orofacial clefts in humans

\begin{tabular}{|l|l|l|l|l|l|}
\hline Gene & Gene symbol & Loci & OMIM & Evidence & References \\
\hline Special AT-rich sequence-binding protein & SATB2 & $2 q 33.1$ & 608148 & $\mathrm{M}$ & 43,46 \\
\hline B-cell leukemia/lymphoma 3 & BCL3 & $19 q 13.32$ & 109560 & LD, L & 47,49 \\
\hline Distal-less homeobox 4 & DLX4 & $17 q 21.33$ & 601911 & $\mathrm{M}$ & $53,55,56$ \\
\hline Paired box gene 9 & PAX9 & $14 q 13.3$ & 167416 & $\mathrm{~L}$, GWAS & $6,60,62,64$ \\
\hline Netrin 1 & NTN1 & $17 p 13.1$ & 601614 & GWAS & 70,71 \\
\hline T-box transcription factor 22 & TBX22 & Xq21.1 & 300307 & M, LD & $75,77,79$ \\
\hline Poliovirus receptor like-1 & PVRL1 & $11 q 23.3$ & 600644 & M, LD,GWAS & $81,83,85$ \\
\hline Cleft lip and palate associated transmembrane protein 1 & CLPTM1 & $19 q 13.32$ & 604783 & M, L, LD & 89,90 \\
\hline MAF bZIP transcription factor B & MAFB & $20 q 12$ & 608968 & GWAS & 98,101 \\
\hline Fibroblast growth factor receptor 1 & FGFR1 & $8 \mathrm{p} 11.23$ & 136350 & M, D & 102,103 \\
\hline Transcription factor AP2- $\alpha$ & TFAP2A & $6 \mathrm{p} 24.3$ & 107580 & $\mathrm{D}, \mathrm{L}$ & 104 \\
\hline S-glutathione transferase T1 & GSTT1 & $22 q 11.2$ & 600436 & LD & 108,109 \\
\hline Receptor-like tyrosine kinase & RYK & $3 q 22.2$ & 600524 & $\mathrm{M}$ & 110,111 \\
\hline Gamma-aminobutyric acid receptor, Beta-3 & GABRB3 & $15 q 12$ & 137192 & GWAS & 112 \\
\hline ATP-binding cassette, subfamily A, member 4 & ABCA4 & $1 \mathrm{p} 22.1$ & 601691 & GWAS & $115,117,118$ \\
\hline
\end{tabular}

Abbreviations: D, deletions; GWAS, genome-wide association studies; L, linkage; LD, linkage disequilibrium; M, mutations; OMIM, Online Mendelian Inheritance in Man.

populations have implicated the role of BCL3 in development of NSCL/P. It was found that BCL3 contributes to the regulation of cell proliferation, and cell cycle regulation can cause a disturbance in facial formation. ${ }^{49} \mathrm{~A}$ study also reported BCL3 contribution in angiogenesis-related genes in the etiology of CLP. ${ }^{50}$ However, no association of BCL3 gene with NSCLP was found in multigenerational families of Indian population. ${ }^{51}$

\section{Distal-Less Homeobox 4}

Distal-Less Homeobox 4 (DLX4) belongs to DLX gene family containing a homeobox transcription factor which plays an important role in craniofacial development and palatogenesis. It is located on chromosome $17 q 21.33$ and causes orofacial cleft 15 (OFC15) and cleft lip/palate. In an animal study, the DLX genes caused cleft palate showing the importance of these genes in craniofacial morphogenesis. ${ }^{52}$ Whole-exome sequencing study in a Hispanic mother and son with bilateral CLP confirmed the DLX4 as a potential cause of oral clefts. ${ }^{53-55}$ Recently, a study showed that none of the distal-less 4 (DLX4) gene SNPs were associated with NSOCs, so it should be interpreted with a caution in the etiology of nonsyndromic orofacial clefts. ${ }^{56}$

\section{Paired Box Gene 9}

Paired Box Gene 9 (PAX9) is a member of the paired box (PAX) family of transcription factors and contains a paired box domain, an octapeptide, and a paired-type homeodomain. It plays a critical role during neural crest and fetal development. PAX9 is located on chromosome 14q13.3, consists of five exons, and associated with the formation of the teeth and palate. ${ }^{57,58}$ Tooth agenesis and the formation of a cleft palate in PAX9-deficient mice have been reported. ${ }^{59}$
Schuffenhauer et al, first reported the role of PAX9 in a patient presented with bilateral CLP. ${ }^{60}$ A linkage analysis of PAX9 gene in two large families and four unrelated families showed that the hypodontia primarily involving molars, suggested that the mutant PAX9 protein acquires functional defects in DNA binding, as well as the loss of function of PAX9 resulting in haploinsufficiency during the morphogenesis of the dentition and the subsequent tooth agenesis. ${ }^{61,62}$ Several studies identified mutations at PAX9 may increase the risk of NS cleft lip with or without palate. ${ }^{63-66}$

A combined genome-wide association study (GWAS) used unmixed NS CPO and NS CLO subtypes suggested that PAX9 is a strong genetic factor for NS CPO in the Chinese population. Mutation analysis of PAX9 SNPs rs12885612 and rs 12881248 revealed that PAX9 is a promising susceptible gene for NS CLO in Western Han Chinese population. 5,6

\section{Netrin 1 (NTN1)}

The netrin 1 (OMIM: 601614) located on chromosome 17p13.1 is a family of laminin-related secreted proteins. Its functions include axon guidance and cell migration in the central nervous system, angiogenesis, and semicircular canal formation.

NTN1 is expressed at high levels in cells that will come together to form a fusion plate, a prerequisite for the formation of semicircular canals. In netrin 1 mutant mice, fusion plate formation is severely affected, and it stimulates proliferation of the periotic mesenchymal cells which then push the epithelial cell walls together to form the fusion plate. ${ }^{67,68}$ It affects the development of the craniofacial region and has been shown to play a vital role in regulating cell migration during embryogenesis, and it is also expressed in the medial edges and oral sides of the palatal shelves. ${ }^{69}$ 
A GWAS included 1,409 case-parent trios by several research groups with samples of Asian or European ancestry from Europe, the United States, China, and the Philippines found NTN1 role in the etiology of NSCLP. ${ }^{70}$ A case-control study of NTN1, identified SNP (rs9788972) as a risk locus for NSOCs susceptibility in a northern Chinese population. ${ }^{71}$

\section{T-Box Transcription Factor 22}

The T-box 22 (TBX22) gene encodes transcription factors involved in the regulation of developmental processes and plays a major role in human palatogenesis. It contains eight coding exons. TBX22 cause X-linked cleft palate and is characterized by isolated cleft palate and ankyloglossia. ${ }^{72}$ It is expressed in the developing palatal shelves and at the base of the tongue prior to elevation to a horizontal position above the tongue. $^{73}$

Genome-wide linkage analysis showed the association of TBX22 role in the development of NSCLP. ${ }^{74}$ In addition, mutations in TBX22 were found in individuals with isolated $\mathrm{CPO} .^{75-77}$ It plays a significant role in tooth and upper lip development and causes hypodontia and cleft lip. ${ }^{78}$ DNA methylation study suggests that cleft palate-susceptible gene Tbx22 is associated with gene expression and might be responsible for the developmental failure of palatal fusion, eventually resulting in the formation of cleft palate. ${ }^{79}$

\section{Poliovirus Receptor-Like 1}

Poliovirus receptor-like 1 (PVRL1), also known as NECTIN1 (nectin cell adhesion molecule 1) belongs to the nectin subfamily of immunoglobulin-like adhesion molecules that involve cell-cell adhesion. It plays a vital role in the organization of adherens junctions and tight junctions in epithelial and endothelial cells. ${ }^{80}$ During the developmental process, the palatal shelves and palatal epithelium come in close contact and fuse together. PVRL1 plays a major role in these developments during palatogenesis and genetic variations reported to have a significant relationship with CLP. Diseases associated with PVRL1 include cleft lip/palate-ectodermal dysplasia syndrome (CLPED) and herpes simplex.

In animal experiments, PVRL1 expressed at the medial edge epithelium of the palatal shelves and the skin surface epithelium locations that corresponded to the clinical phenotypes of CLPED and in humans, mutations of the PVRL1 gene resulting CLPED in families from Israel and Brazil. ${ }^{81}$ Interestingly, heterozygous mutation of PVRL1 (W185X) associated with NSCLP in northern Venezuela ${ }^{82,83}$ and two novel variants of the PVRL1 gene were identified in Turkish NSCLP patients. ${ }^{84}$ In an experimental animal studies, PVRL1 expressed at the medial edge epithelium of the palatal shelves and the skin surface epithelium locations that corresponded to the clinical phenotypes of CLPED and in humans, mutations of the PVRL1 genes caused CLPED in Israel and Brazilian population. ${ }^{85-88}$

\section{Cleft Lip and Palate-Associated Transmembrane Protein 1}

Cleft lip and palate-associated transmembrane protein 1 (CLPTM1) is a multipass transmembrane protein that regulates
GABA-A receptors (e.g., GABRA1) and modulates inhibitory synaptic strength. It is located on chromosome 19q13.3 and plays a role in T-cell development. Mutation of CLPTM1 genes suggested that a regulatory element in this gene region get affected and which is responsible for the development of orofacial clefts. ${ }^{89,90}$ However, some studies contradict the role of CLPTM1 in the etiology of NSCL/P as no evidence of an association with oral clefts was found among the SNPS of CLPTM1 selected for testing in Japanese and Irish population. ${ }^{91,92}$

\section{MAF bZIP Transcription Factor $B$}

The MAF bZIP Transcription Factor B (MAFB) gene encodes a basic leucine zipper (bZIP) transcription factor that plays an important role in the regulation of lineage-specific hematopoiesis. It is located on chromosome 20q11.2, consists of a single exon and spans approximately $3 \mathrm{~kb} .{ }^{93}$ In a mouse study, MAFB was expressed in the palatal shelves and the medial edge epithelia (or MEE) during palatal fusion. ${ }^{94}$ Mutations in the MAFB gene reported causing multicentric carpotarsal osteolysis syndrome and Duane retraction syndrome 3 with or without deafness. ${ }^{95,96}$

Several GWAS in European and Asian populations identified the role of MAFB in NS CLP. ${ }^{97,98}$ Different systematic review and meta-analyses confirmed that the MAFB gene SNP (rs13041247) is associated with NSCL/P risk in different population; however, this association is not significant in East Asian or Caucasian populations, ${ }^{99,100}$ whereas, the SNPs rs17820943 and rs6072081 of MAFB found to be associated with NSCLP in an East Asian population. ${ }^{101}$

\section{Other Candidate Genes}

A variety of genetic approaches have identified several genes located on different chromosomes, contributing to etiology of NSCLP. Advances in genetics and molecular biology techniques have led the way to the discovery of genetic variation involved in NSCLP. Genes such as FGFR1, TFAP2A, GSTT1, receptor-like tyrosine kinase (RYK), and ABCA4 have also been found to be associated with NSCLP.

Riley et al assessed the genes involved in the fibroblast growth factor (FGF) signaling pathway and identified the functional impairment in the FGFR1 gene in NSCLP families and suggested that the FGF signaling pathway may contribute to as much as 3 to $5 \%$ of NS cleft lip or palate. ${ }^{102} \mathrm{Xu}$ et al reported mutations of the FGFR1 gene in Chinese Kallmann syndrome males with cleft lip/palate. ${ }^{103}$ TFAP2A located on $6 \mathrm{p} 24$ region has been associated with orofacial clefting. Davies et al reported a patient with cleft palate, microretrognathia, frontal bossing, hypertelorism, flat, broad nasal bridge, low set ears, and developmental delay. ${ }^{104}$ However, it was found that there was no significant association between TFAP2A and NSCLP in this northern Chinese ${ }^{105}$ and Indian population. ${ }^{106}$ S-glutathione transferase T1 (GSTT1) play an important role in the detoxification and secretion of smoking byproducts and deficiency of this enzyme may cause a greater risk of NSCLP if the individuals were exposed to smoking byproducts during pregnancy. ${ }^{107,108}$ Hozyasz et al suggested that homozygous deletion of GSTT1 in mother genome might increase the risk of having a child with NSCLP. ${ }^{109}$ 
Further, mutations in the $R Y K$ gene were also found to be associated with orofacial clefting. ${ }^{110,111}$ Significant linkage disequilibrium between Gamma-aminobutyric acid receptor, Beta-3 (GABRB3), and CLP was reported by Scapoli et al and this finding in humans is in agreement with previously reported data obtained with the murine model. ${ }^{112}$ In addition, Baroni et al and Carter et al reported the association of GABRB3 with oral clefts in different populations. ${ }^{113,114}$ ATPbinding cassette, subfamily A, member 4 (ABCA4) encodes an ATP-binding cassette transporter. Several linkages and GWAS showed the role of ABCA4 in NSCLP with stronger evidence among Asian samples. ABCA4 is known to cause the autosomal-recessive retinal degenerative disease Stargardt's disease. A GWAS and a case-parent trio approach by Beaty et al identified $A B C A 4$ gene association with NSCLP ${ }^{115,116}$ and several other studies also reported a potential role of $A B C A 4$ in the etiology of $\mathrm{CL} / \mathrm{P}$ in Brazilian and northern Chinese Han population. ${ }^{117,118}$

\section{Conclusion}

Genetic studies provide insight into the multiple genes involved in the etiology of OFCs. Identification of specific genetic causes of clefts helps for better understanding of the molecular pathogenesis of OFC. In the near future, it helps to provide a more accurate diagnosis, genetic counseling, personalized medicine for better clinical care and prevention of OFCs.

Conflict of Interest

None declared.

\section{References}

1 Wong FK, Hagg U. An update on the aetiology of orofacial clefts. Hong Kong Med J 2004;10(05):331-336

2 Mossey P. Epidemiology underpinning research in the aetiology of orofacial clefts. Orthod Craniofac Res 2007;10(03):114-120

3 Rahimov F, Jugessur A, Murray JC. Genetics of nonsyndromic orofacial clefts. Cleft Palate Craniofac J 2012;49(01):73-91

4 Worley ML, Patel KG, Kilpatrick LA. Cleft lip and palate. Clin Perinatol 2018;45(04):661-678

5 Huang L, Jia Z, Shi Y, et al. Genetic factors define CPO and CLO subtypes of nonsyndromicorofacial cleft. PLoS Genet 2019;15 (10): 1008357

6 Yang CW, Shi JY, Yin B, Shi B, Jia ZL. Mutation at paired box gene 9 is associated with non-syndromic cleft lip only from Western Han Chinese population. Arch Oral Biol 2020;117:104829

7 Martinelli M, Palmieri A, Carinci F, Scapoli L. Non-syndromic cleft palate: an overview on human genetic and environmental risk factors. Front Cell Dev Biol 2020;8:592271

8 Jugessur A, Farlie PG, Kilpatrick N. The genetics of isolated orofacial clefts: from genotypes to subphenotypes. Oral Dis 2009;15(07):437-453

9 do Rego Borges A, Sá J, Hoshi R, et al. Genetic risk factors for nonsyndromic cleft lip with or without cleft palate in a Brazilian population with high African ancestry. Am J Med Genet A 2015; 167A(10):2344-2349

10 Saad AN, Parina RP, Tokin C, Chang DC, Gosman A. Incidence of oral clefts among different ethnicities in the state of California. Ann Plast Surg 2014;72(Suppl 1):S81-S83

11 Ghazali N, Rahman NA, Kannan TP, Jaafar S. Screening of transforming growth factor Beta 3 and Jagged2 genes in the Malay population with nonsyndromic cleft lip with or without cleft palate. Cleft Palate Craniofac J 2015;52(04):e88-e94

12 Hoffman-Andrews L, Tarnowski JM, Lee S, et al. Characteristics of orofacial clefting in Hawai'i. Hawaii J Health Soc Welf 2019;78 (08):258-261

13 Dixon MJ, Marazita ML, Beaty TH, Murray JC. Cleft lip and palate: understanding genetic and environmental influences. Nat Rev Genet 2011;12(03):167-178

14 Leslie EJ, Marazita ML. Genetics of cleft lip and cleft palate. Am J Med Genet C Semin Med Genet 2013;163C(04):246-258

15 Neela PK, Gosla SR, Husain A, Mohan V. CRISPLD2 gene polymorphisms with nonsyndromic cleft lip palate in Indian population. Glob Med Genet 2020;7(01):22-25

16 Hagberg C, Larson O, Milerad J. Incidence of cleft lip and palate and risks of additional malformations. Cleft Palate Craniofac J 1998;35(01):40-45

17 Ogle OE. Incidence of cleft lip and palate in a newborn Zairian sample. Cleft Palate Craniofac J 1993;30(02):250-251

18 Wyszynski DF, Wu T. Use of US birth certificate data to estimate the risk of maternal cigarette smoking for oral clefting. Cleft Palate Craniofac J 2002;39(02):188-192

19 Yang J, Carmichael SL, Canfield M, Song J, Shaw GMNational Birth Defects Prevention Study. Socioeconomic status in relation to selected birth defects in a large multicentered US case-control study. Am J Epidemiol 2008;167(02):145-154

20 Croen LA, Shaw GM, Wasserman CR, Tolarová MM. Racial and ethnic variations in the prevalence of orofacial clefts in California, 1983-1992. Am J Med Genet 1998;79(01):42-47

21 Mossey PA, Little J, Munger RG, Dixon MJ, Shaw WC. Cleft lip and palate. Lancet 2009;374(9703):1773-1785

22 Parker SE, Mai CT, Canfield MA, et al;National Birth Defects Prevention Network. Updated National Birth Prevalence estimates for selected birth defects in the United States, 2004-2006. Birth Defects Res A Clin Mol Teratol 2010;88(12):1008-1016

23 Neela PK, Gosla SR, Husain A, Mohan V, Thumoju S, Rajeshwari BV. Analysis of single nucleotide polymorphisms on locus 13q33.1-34 in multigenerational families of cleft lip palate using mass array. Indones Biomed J. 2020; In press

24 Bender PL. Genetics of cleft lip and palate. J Pediatr Nurs 2000;15 (04):242-249

25 Neela PK, Gosla SR, Husain A, Mohan V, Thumoju S, Bv R. Association of MAPK4 and SOX1-OT gene polymorphisms with cleft lip palate in multiplex families: a genetic study. J Dent Res Dent Clin Dent Prospect 2020;14(02):93-96

26 Wyszynski DF, Wu T. Prenatal and perinatal factors associated with isolated oral clefting. Cleft Palate Craniofac J 2002;39(03): 370-375

27 Cobourne MT. Cleft Lip and Palate. Epidemiology, Aetiology and Treatment. Front Oral Biol London: Karger; 2012:60-70

28 Singh I, Pal GP. Human Embryology. 7th ed. Delhi: Macmillan India Ltd; 2001:130-131

29 Jiang R, Bush JO, Lidral AC. Development of the upper lip: morphogenetic and molecular mechanisms. Dev Dyn 2006; 235(05):1152-1166

30 Stanier P, Moore GE. Genetics of cleft lip and palate: syndromic genes contribute to the incidence of non-syndromic clefts. Hum Mol Genet 2004;13(Spec No 1):R73-R81

31 Gritli-Linde A. Molecular control of secondary palate development. Dev Biol 2007;301(02):309-326

32 Bush JO, Jiang R. Palatogenesis: morphogenetic and molecular mechanisms of secondary palate development. Development 2012;139(02):231-243

33 Fogh Andersen P. Inheritance of harelip and cleft palate. Copenhagen: Busck; 1942

34 Fraser FC, Baxter $\mathrm{H}$. The familial distribution of congenital clefts of the lip and palate; a preliminary report. Am J Surg 1954;87 (05):656-659 
35 Fraser FC. The genetics of cleft lip and cleft palate. Am J Hum Genet 1970;22(03):336-352

36 Marazita ML, Spence MA, Melnick M. Genetic analysis of cleft lip with or without cleft palate in Danish kindreds. Am J Med Genet 1984;19(01):9-18

37 Mitchell LE. Mode of inheritance of oral clefts. In: Wyszyski DF, ed. Cleft Lip and Palate: From Origin to Treatment. New York, NY: Oxford University Press; 2002:234-239

38 Grosen D, Bille C, Pedersen JK, Skytthe A, Murray JC, Christensen K. Recurrence risk for offspring of twins discordant for oral cleft: a population-based cohort study of the Danish 1936-2004 cleft twin cohort. Am J Med Genet A 2010;152A(10): 2468-2474

39 Chung KC, Kowalski CP, Kim HM, Buchman SR. Maternal cigarette smoking during pregnancy and the risk of having a child with cleft lip/palate. Plast Reconstr Surg 2000;105(02):485-491

40 Bhaskar LV, Murthy J, Venkatesh Babu G. Polymorphisms in genes involved in folate metabolism and orofacial clefts. Arch Oral Biol 2011;56(08):723-737

41 Sabbagh HJ, Innes NP, Sallout BI, et al. Birth prevalence of nonsyndromic orofacial clefts in Saudi Arabia and the effects of parental consanguinity. Saudi Med J 2015;36(09):1076-1083

42 Neela PK, Reddy SG, Husain A, Mohan V. Association of cleft lip and/or palate in people born to consanguineous parents: a 13year retrospective study from a very high volume cleft center. J Cleft Lip Palate Craniofacial Anomalies 2019;6:33-37

43 FitzPatrick DR, Carr IM, McLaren L, et al. Identification of SATB2 as the cleft palate gene on 2q32-q33. Hum Mol Genet 2003;12 (19):2491-2501

44 Britanova O, Depew MJ, Schwark M, et al. SATB2 haploinsufficiency phenocopies 2q32-q33 deletions, whereas loss suggests a fundamental role in the coordination of jaw development. Am J Hum Genet 2006;79(04):668-678

45 Leoyklang P, Suphapeetiporn K, Siriwan P, et al. Heterozygous nonsense mutation SATB2 associated with cleft palate, osteoporosis, and cognitive defects. Hum Mutat 2007;28(07):732-738

46 Grassia V, Lombardi A, Kawasaki H, et al. Salivary microRNAs as new molecular markers in cleft lip and palate: a new frontier in molecular medicine. Oncotarget 2018;9(27):18929-18938

47 Martinelli M, Scapoli L, Pezzetti F, et al. Suggestive linkage between markers on chromosome 19q13.2 and nonsyndromic orofacial cleft malformation. Genomics 1998;51(02):177-181

48 Park BY, Sull JW, Park JY, Jee SH, Beaty TH. Differential parental transmission of markers in BCL3 among Korean cleft case-parent trios. J Prev Med Public Health 2009;42(01):1-4

49 Lace B, Kempa I, Klovins J, et al. BCL3 gene role in facial morphology. Birth Defects Res A Clin Mol Teratol 2012;94(11):918-924

50 François-Fiquet C, Poli-Merol ML, Nguyen P, Landais E, Gaillard D, Doco-Fenzy M. Role of angiogenesis-related genes in cleft lip/palate: review of the literature. Int J Pediatr Otorhinolaryngol 2014;78(10):1579-1585

51 Neela PK, Gosla SR, Husain A, Mohan V, Thumoju S, Rajeshwari BV. Association of nucleotide variants of GRHL3, IRF6, NAT2, SDC2, BCL3 and PVRL1 genes with non-syndromic cleft lip with/without cleft palate in multigenerational families: a retrospective study. Contemp Clin Dent 2020; In press

52 Talbot JC, Johnson SL, Kimmel CB. hand2 and Dlx genes specify dorsal, intermediate and ventral domains within zebrafish pharyngeal arches. Development 2010;137(15):2507-2517

53 Murthi P, Said JM, Doherty VL, et al. Homeobox gene DLX4 expression is increased in idiopathic human fetal growth restriction. Mol Hum Reprod 2006;12(12):763-769

54 Zhang L, Yang M, Gan L, et al. DLX4 upregulates TWIST and enhances tumor migration, invasion and metastasis. Int J Biol Sci 2012;8(08):1178-1187

55 Wu D, Mandal S, Choi A, et al. DLX4 is associated with orofacial clefting and abnormal jaw development. Hum Mol Genet 2015; 24(15):4340-4352
56 He M, Bian Z. Association between DLX4 polymorphisms and nonsyndromicorofacial clefts in a Chinese Han population. Cleft Palate Craniofac J 2019;56(03):357-362

57 Bonczek O, Balcar VJ, Šerý O PAX9 gene mutations and tooth agenesis: a review. Clin Genet 2017;92(05):467-476

58 Li R, Chen Z, Yu Q, Weng M, Chen Z. The function and regulatory network of PAX9 gene in palate development. J Dent Res 2019;98 (03):277-287

59 Peters H, Neubüser A, Kratochwil K, Balling R. PAX9-deficient mice lack pharyngeal pouch derivatives and teeth and exhibit craniofacial and limb abnormalities. Genes Dev 1998;12(17): 2735-2747

60 Schuffenhauer S, Leifheit HJ, Lichtner P, Peters H, Murken J, Emmerich P. De novo deletion (14)(q11.2q13) including PAX9: clinical and molecular findings. J Med Genet 1999;36(03):233-236

61 Das P, Hai M, Elcock C, et al. Novel missense mutations and a 288bp exonic insertion in PAX9 in families with autosomal dominant hypodontia. Am J Med Genet A 2003;118A(01):35-42

62 Zhao JL, Chen YX, Bao L, Xia QJ, Wu TJ, Zhou L. Novel mutations of PAX9 gene in Chinese patients with oligodontia. Zhonghua Kou Qiang Yi Xue Za Zhi 2005;40(04):266-270

63 Sull JW, Liang KY, Hetmanski JB, et al. Maternal transmission effects of the PAX genes among cleft case-parent trios from four populations. Eur J Hum Genet 2009;17(06):831-839

64 Nakatomi M, Wang XP, Key D, et al. Genetic interactions between PAX9 and Msx1 regulate lip development and several stages of tooth morphogenesis. Dev Biol 2010;340(02):438-449

65 Song T, Wu D, Wang Y, Li H, Yin N, Zhao Z. SNPs and interaction analyses of IRF6, MSX1 and PAX9 genes in patients with nonsyndromic cleft lip with or without palate. Mol Med Rep 2013;8 (04):1228-1234

66 de Araujo TK, Secolin R, Félix TM, et al. A multicentric association study between 39 genes and nonsyndromic cleft lip and palate in a Brazilian population. J Craniomaxillofac Surg 2016;44(01):16-20

67 Serafini T, Colamarino SA, Leonardo ED, et al. Netrin-1 is required for commissural axon guidance in the developing vertebrate nervous system. Cell 1996;87(06):1001-1014

68 Salminen M, Meyer BI, Bober E, Gruss P. Netrin 1 is required for semicircular canal formation in the mouse inner ear. Development 2000;127(01):13-22

69 Srinivasan K, Strickland P, Valdes A, Shin GC, Hinck L. Netrin-1/ neogenin interaction stabilizes multipotent progenitor cap cells during mammary gland morphogenesis. Dev Cell 2003;4(03): 371-382

70 Leslie EJ, Taub MA, Liu H, et al. Identification of functional variants for cleft lip with or without cleft palate in or near PAX7, FGFR2, and NOG by targeted sequencing of GWAS loci. Am J Hum Genet 2015;96(03):397-411

71 Guo Q Li D, Meng X, et al. Association between PAX7 and NTN1 gene polymorphisms and nonsyndromicorofacial clefts in a northern Chinese population. Medicine (Baltimore) 2017; 96:19 (e6724)

72 Braybrook C, Doudney K, Marçano AC, et al. The T-box transcription factor gene TBX22 is mutated in X-linked cleft palate and ankyloglossia. Nat Genet 2001;29(02):179-183

73 Braybrook C, Lisgo S, Doudney K, et al. Craniofacial expression of human and murine TBX22 correlates with the cleft palate and ankyloglossia phenotype observed in CPX patients. Hum Mol Genet 2002;11(22):2793-2804

74 Prescott NJ, Lees MM, Winter RM, Malcolm S. Identification of susceptibility loci for nonsyndromic cleft lip with or without cleft palate in a two stage genome scan of affected sib-pairs. Hum Genet 2000;106(03):345-350

75 Marçano AC, Doudney K, Braybrook C, et al. TBX22 mutations are a frequent cause of cleft palate. J Med Genet 2004;41(01):68-74

76 Suphapeetiporn K, Tongkobpetch S, Siriwan P, Shotelersuk V. TBX22 mutations are a frequent cause of non-syndromic cleft palate in the Thai population. Clin Genet 2007;72(05):478-483 
77 Dai J, Xu C, Wang G, et al. Novel TBX22 mutations in Chinese nonsyndromic cleft lip/palate families. J Genet 2018;97(02): 411-417

78 Kantaputra PN, Paramee M, Kaewkhampa A, et al. Cleft lip with cleft palate, ankyloglossia, and hypodontia are associated with TBX22 mutations. J Dent Res 2011;90(04):450-455

79 Shu X, Dong Z, Cheng L, Shu S. DNA hypermethylation of Fgf16 and Tbx22 associated with cleft palate during palatal fusion. J Appl Oral Sci 2019;27:e20180649

80 Takahashi K, Nakanishi H, Miyahara M, et al. Nectin/PRR: an immunoglobulin-like cell adhesion molecule recruited to cadherin-based adherens junctions through interaction with Afadin, a PDZ domain-containing protein. J Cell Biol 1999;145(03): 539-549

81 Suzuki K, Hu D, Bustos T, et al. Mutations of PVRL1, encoding a cell-cell adhesion molecule/herpesvirus receptor, in cleft lip/palate-ectodermal dysplasia. Nat Genet 2000;25(04): 427-430

82 Sözen MA, Suzuki K, Tolarova MM, Bustos T, Fernández Iglesias JE, Spritz RA. Mutation of PVRL1 is associated with sporadic, non-syndromic cleft lip/palate in northern Venezuela. Nat Genet 2001;29(02):141-142

83 Scapoli L, Palmieri A, Martinelli M, et al. Study of the PVRL1 gene in Italian nonsyndromic cleft lip patients with or without cleft palate. Ann Hum Genet 2006;70(Pt 3):410-413

84 Oner DA, Tastan H. Identification of novel variants in the PVRL1 gene in patients with nonsyndromic cleft lip with or without cleft palate. Genet Test Mol Biomarkers 2016;20(05):269-272

85 Avila JR, Jezewski PA, Vieira AR, et al. PVRL1 variants contribute to non-syndromic cleft lip and palate in multiple populations. Am J Med Genet A 2006;140(23):2562-2570

86 Sözen MA, Hecht JT, Spritz RA. Mutation analysis of the PVRL1 gene in Caucasians with nonsyndromic cleft lip/palate. Genet Test Mol Biomarkers 2009;13(05):617-621

87 Cheng HQ Huang EM, Xu MY, Shu SY, Tang SJ. PVRL1 as a candidate gene for nonsyndromic cleft lip with or without cleft palate: no evidence for the involvement of common or rare variants in southern Han Chinese patients. DNA Cell Biol 2012;31 (07):1321-1327

88 Shu SY, Zhang MJ, Cheng HQ et al. Mutation analysis of PVRL1 in patients with non-syndromic cleft of the lip and/or palate in Guangdong. Genet Mol Res 2015;14(02):3400-3408

89 Yoshiura K, Machida J, Daack-Hirsch S, et al. Characterization of a novel gene disrupted by a balanced chromosomal translocation $\mathrm{t}$ $(2 ; 19)(q 11.2 ; q 13.3)$ in a family with cleft lip and palate. Genomics 1998;54(02):231-240

90 Warrington A, Vieira AR, Christensen K, et al. Genetic evidence for the role of loci at 19q13 in cleft lip and palate. J Med Genet 2006;43(06):e26

91 Ichikawa E, Watanabe A, Nakano Y, et al. PAX9 and TGFB3 are linked to susceptibility to nonsyndromic cleft lip with or without cleft palate in the Japanese: population-based and family-based candidate gene analyses. J Hum Genet 2006;51(01):38-46

92 Carter TC, Molloy AM, Pangilinan F, et al. Testing reported associations of genetic risk factors for oral clefts in a large Irish study population. Birth Defects Res A Clin Mol Teratol 2010;88 (02):84-93

93 Wang PW, Eisenbart JD, Cordes SP, Barsh GS, Stoffel M, Le Beau MM. Human KRML (MAFB): cDNA cloning, genomic structure, and evaluation as a candidate tumor suppressor gene in myeloid leukemias. Genomics 1999;59(03):275-281

94 Beaty TH, Murray JC, Marazita ML, et al. A genome-wide association study of cleft lip with and without cleft palate identifies risk variants near MAFB and ABCA4. Nat Genet 2010;42(06): 525-529

95 Zankl A, Duncan EL, Leo PJ, et al. Multicentric carpotarsal osteolysis is caused by mutations clustering in the amino- terminal transcriptional activation domain of MAFB. Am J Hum Genet 2012;90(03):494-501

96 Park JG, Tischfield MA, Nugent AA, et al. Loss of MAFB function in humans and mice causes Duane syndrome, aberrant extraocular muscle innervation, and inner-ear defects. Am J Hum Genet 2016;98(06):1220-1227

$97 \mathrm{Mi} \mathrm{N}$, Hao Y, Jiao X, et al. Association study of single nucleotide polymorphisms of MAFB with non-syndromic cleft lip with or without cleft palate in a population in Heilongjiang Province, northern China. Br J Oral Maxillofac Surg 2014;52(08):746-750

98 He Y, Huang L, Zheng Y, Chen JH, Tang S. Association of single nucleotide polymorphisms at 20q12 with nonsyndromic cleft lip with or without cleft palate in a Southern Chinese Han cohort. Mol Genet Genomic Med 2020;8(01):e1028

99 Imani MM, Lopez-Jornet P, Pons-Fuster López E, Sadeghi M. Polymorphic variants of V-Maf musculoaponeurotic fibrosarcoma oncogene homolog B (rs13041247 and rs11696257) and risk of non-syndromic cleft lip/palate: systematic review and metaanalysis. Int J Environ Res Public Health 2019;16(15):2792

100 Huang L, Liang X, Ou Y, Tang S, He Y. Association between $20 q 12$ rs13041247 polymorphism and risk of nonsyndromic cleft lip with or without cleft palate: a meta-analysis. BMC Oral Health 2020;20(01):39

101 Liang X, Huang L, Ou Y, He Y, Tang S. Association between MAFB rs17820943 and rs6072081 polymorphism and risk of nonsyndromic cleft lip with or without cleft palate: a meta-analysis. $\mathrm{Br} \mathrm{J}$ Oral Maxillofac Surg 2020;58(09):1065-1072

102 Riley BM, Mansilla MA, Ma J, et al. Impaired FGF signaling contributes to cleft lip and palate. Proc Natl Acad Sci U S A 2007;104(11):4512-4517

$103 \mathrm{Xu} \mathrm{H}$, Niu Y, Wang T, et al. Novel FGFR1 and KISS1R mutations in Chinese Kallmann syndrome males with cleft lip/palate. BioMed Res Int 2015;2015:649698

104 Davies AF, Imaizumi K, Mirza G, et al. Further evidence for the involvement of human chromosome 6p24 in the aetiology of orofacial clefting. J Med Genet 1998;35(10):857-861

105 Shi J, Song T, Jiao X, Qin C, Zhou J. Single-nucleotide polymorphisms (SNPs) of the IRF6 and TFAP2A in non-syndromic cleft lip with or without cleft palate (NSCLP) in a northern Chinese population. Biochem Biophys Res Commun 2011;410(04): 732-736

106 Babu Gurramkonda V, Syed AH, Murthy J, , V K S Lakkakula B. Association of TFAP2A gene polymorphism with susceptibility to non-syndromic cleft lip with or without palate risk in south Indian population. Meta Gene 2016;9:181-184

107 Cobourne MT. The complex genetics of cleft lip and palate. Eur J Orthod 2004;26(01):7-16

108 Shi M, Christensen K, Weinberg CR, et al. Orofacial cleft risk is increased with maternal smoking and specific detoxificationgene variants. Am J Hum Genet 2007;80(01):76-90

109 Hozyasz KK, Mostowska A, Surowiec Z, Jagodziński PP. [Genetic polymorphisms of GSTM1 and GSTT1 in mothers of children with isolated cleft lip with or without cleft palate]. Przegl Lek 2005;62 (10):1019-1022

110 Watanabe A, Akita S, Tin NT, et al. A mutation in RYK is a genetic factor for nonsyndromic cleft lip and palate. Cleft Palate Craniofac J 2006;43(03):310-316

111 Smane L, Pilmane M. IRF6, RYK, and PAX9 expression in facial tissue of children with cleft palate. Int J Morphol 2015;33:647-652

112 Scapoli L, Martinelli M, Pezzetti F, et al. Linkage disequilibrium between GABRB3 gene and nonsyndromic familial cleft lip with or without cleft palate. Hum Genet 2002;110(01):15-20

113 Baroni T, Bellucci C, Lilli C, et al. Retinoic acid, GABA-ergic, and TGF-beta signaling systems are involved in human cleft palate fibroblast phenotype. Mol Med 2006;12(9-10):237-245

114 Vieira AR, Howe A, Murray JC. Studies of $\gamma$-aminobutyric acid type A receptor $\beta 3$ (GABRB3) and glutamic acid decarboxylase 67 
108 Genetic Factors in Nonsyndromic Orofacial Clefts Khan et al.

(GAD67) with oral clefts. Am J Med Genet A 2008;146A(21): 2828-2830

115 Fontoura C, Silva RM, Granjeiro JM, Letra A. Further evidence of association of the $A B C A 4$ gene with cleft lip/palate. Eur J Oral Sci 2012;120(06):553-557

116 Beaty TH, Taub MA, Scott AF, et al. Confirming genes influencing risk to cleft lip with/without cleft palate in a case-parent trio study. Hum Genet 2013;132(07):771-781

117 Mi N, Hao Y, Jiao X, Zheng X, Shi J, Chen Y. A polymorphic marker associated with non-syndromic cleft lip with or without cleft palate in a population in Heilongjiang Province, northern China. Arch Oral Biol 2015;60(02):357-361
118 Peng HH, Chang NC, Chen KT, et al. Nonsynonymous variants in MYH9 and ABCA4 are the most frequent risk loci associated with nonsyndromic orofacial cleft in Taiwanese population. BMC Med Genet 2016;17(01):59

\section{Web References}

National Center for Biotechnology Information (NCBI). Available at: http://www.ncbi.nih.gov/. Accessed August 20, 2020

Online Mendelian Inheritance in Man (OMIM). Available at: http://www.ncbi.nlm.nih.gov/omim/. Accessed August 20, 2020 